\title{
Effects of Vitamin D Serum Level on Morbidity and Mortality in Patients with COVID-19: A Systematic Review and Meta-Analysis
}

\author{
Yiyun $\mathrm{Hu}^{1}$, Janice Y. Kung ${ }^{2}$, Andrew Cave ${ }^{3}$, Hoan Linh Banh ${ }^{3}$ \\ ${ }^{1}$ Department of Pharmacy, The Second Xiangya Hospital, Central South University, Changsha, China; ${ }^{2}$ John W. Scott Health \\ Sciences Library, University of Alberta; 3 Department of Family Medicine, Faculty of Medicine and Dentistry, University of \\ Alberta, Edmonton, Alberta, Canada
}

Corresponding authors: Yiyun Hu, Department of Pharmacy, the Second Xiangya Hospital of Central South University, 139 Renmin Middle Rd. Changsha, Hunan, China 410008; email: huyiyun89@126.com; Hoan Linh Banh; Faculty of Medicine and Dentistry/Department of Family Medicine, University of Alberta. 6-10 University Terrace, Edmonton, AB, T6G 2C6, Canada; email: hoan@ualberta.ca

Received, January 20, 2022; Revised, February 2, 2022; Accepted, February 22, 2022; Published, March 2, 2022

\begin{abstract}
Purpose: It has been shown that low Vitamin D serum concentration is associated with increased pneumonia and viral respiratory infections. Vitamin D is readily available, inexpensive, and easy to administer to subjects infected with COVID-19. If effective in reducing the severity of COVID-19, it could be an important and feasible therapeutic intervention. Methods: We performed a systematic review and meta-analysis of the literature to determine the effects of Vitamin D serum concentration on mortality and morbidity in COVID-19 patients. The primary objectives were to determine if Vitamin D serum concentration decrease mortality, ICU admissions, ventilator support, and length of hospital stay in COVID-19 patients. Results: A total of 3572 publications were identified. Ultimately, 20 studies are included. A total of 12,806 patients aged between 42 to 81 years old were analyzed. The pooled estimated RR for mortality, ICU admission, ventilator support and length of hospital stay were 1.49 (95\% CI: 1.34, 1.65), 0.87 (95\% CI: 0.67, 1.14), 1.29 (95\% CI: 0.79, 1.84), and 0.84 (95\% CI -0.45, 2.13). Conclusion: There is no statistical difference in mortality, ICU admission rate, ventilator support requirement, and length of hospital stay in COVID-19 patients with low and high Vitamin D serum concentration.
\end{abstract}

\section{INTRODUCTION}

In March 2020, the WHO declared a world pandemic of COVID-19 caused by SARS-CoV-2 infection (1). The infection is associated with severe acute respiratory syndrome resulting from the excessive inflammatory response at 5-7 days. This has a high mortality and patients often require Intensive Care Unit (ICU) care and intubation to cope with the pulmonary response. Another serious complication from COVID-19 is the occurrence of severe thrombotic events affecting limbs, kidneys, or heart (2). In the initial months of the pandemic, there were limited therapeutic treatment options apart from dexamethasone to reduce the body's excessive immune response and no preventive vaccine was yet available.

It has been shown that low Vitamin D serum concentration is associated with increased pneumonia (3) and viral respiratory infections (4). It is postulated that Vitamin D decreases inflammatory mediators such as cytokines (5), platelets (6), and
TNF-alpha (7). Vitamin D also regulates the thrombotic pathways.

Vitamin D is readily available, inexpensive, and easy to administer to patients at risk or recently infected. If effective in reducing the severity of the disease response, this would be an important and feasible therapeutic intervention to reduce the inflammatory response of infectious diseases such as COVID-19. The results from the published studies are conflicting. We therefore performed a systematic review and meta-analysis of the literature to determine the clinical effects of Vitamin D serum concentration in COVID-19 patients. The primary objectives are to determine if Vitamin $\mathrm{D}$ serum concentration affects the mortality in patients with COVID-19. The secondary objectives are to determine if Vitamin D serum concentration affects: 1) ICU admissions, 2) length of hospital stay, and 3) ventilator support requirement. The systematic review and meta-analysis are registered on PROSPERO (CRD42021243290). 


\section{METHOD}

The reporting of this systematic review was guided by the standards of the Preferred Reporting Items for Systematic Review and Meta-Analysis (PRISMA) Statement (8)

\section{Search Strategy}

The medical librarian (JYK) conducted comprehensive searches in Ovid MEDLINE, Ovid Embase, CINAHL, Scopus, Web of Science Core Collection, and Cochrane Library (via Wiley) on May 1, 2021. To capture all relevant literature pertaining to Vitamin D and COVID-19, search filters were used to optimise the comprehensiveness of the search such as adapting the search from a Cochrane review related to Vitamin D (9). The confirmation of the first COVID-19 case in November 2019, (10) search strategies were limited by publication date from 2019 to current. Refer to the appendices for full-text search strategies. A total of 3572 results were retrieved and when all duplicates were removed, 1570 unique results remained for the initial title and abstract screening in a web-based tool called Covidence (11) In addition to subscription databases, the team searched trial registries (e.g., ClinicalTrials.gov) and Google Scholar. The first 200 results from Google Scholar were evaluated for inclusion, which has been demonstrated to be a reasonable number of results to screen since there is high overlap between Web of Science and Google Scholar (12). Bibliographies from included studies were also reviewed (Supplements).

\section{Data extraction and quality assessment}

The references were independently reviewed by two authors (YYH, HLB). Disagreements were resolved by a third author (AC). The data were independently extracted by two authors (YYH, HLB). This included: subject demographic characteristics, first author and year of publication, design of the study, population, intervention, comparator, sample size, and all outcome measures. The meta-analysis consisted of randomized controlled, and observational studies with the following inclusion criteria: 1) COVID-19 positive patients, 2) low Vitamin D serum concentration group, 3) normal Vitamin D serum concentration group, 4) mortality, 5) intensive care unit (ICU) admission, 6) ventilator support, and 7) length of hospital stay. Exclusion criteria were: 1) non-COVID-19 patients, and 2) no serum concentration reported.

\section{STATISTICAL ANALYSIS}

The pooled estimates of odds ratios (ORs) and 95\% confidence intervals (CIs) were calculated to compare the OR of clinical outcomes between the Vitamin D group and a placebo or standard of care group based on the events of reported mortality, ICU admission, ventilator support, and length of hospital stay. $\mathrm{I}^{2}$ statistic was applied to inspect heterogeneity. For $\mathrm{I}^{2}<50 \%$ and $p$ value $>0.1$, heterogeneity was acceptable. For $\mathrm{I}^{2}>50 \%$ and $p$ value $<0.1$, the random effect or a meta-regression method to find sources for the obvious heterogeneity was performed. Because the meta-analysis had less than 10 studies, the funnel plot and Egger test were not used to assess the presence of small study effects. All the statistical analyses were performed in Stata 14.1 (Stata Corp, College Station, TX).

\section{RESULT}

A total of 3572 publications were identified. After 2002 duplications were removed, the abstracts of 1570 papers were screened. 1521 irrelevant publications were removed and full text for the 49 remaining studies were reviewed. Ultimately, 20 studies are included (Figure 1).

\section{Effect of Vitamin D serum concentration on mortality}

The number of deaths reported for low concentration group vs normal concentration group were 819/3125 (26\%) and 2162/9681 (22\%) patients respectively. The overall pooled estimate of risk ratio (RR) for all studies was 1.49 (95\% CI: 1.34, 1.65) using the random effect model with high observed heterogeneity $\left(\mathrm{I}^{2}=83 \%, \mathrm{P}<0.00001\right)$ (Figure 2$)$.

There are $279 / 1531(18 \%)$ deaths in the low serum concentration (measured as 25hydroxyvitamin) group defined as $<20 \mathrm{ng} / \mathrm{mL}$ and $252 / 1369$ (18\%) deaths in the normal serum concentration group defined as $\geq 20 \mathrm{ng} / \mathrm{mL}$. The overall pooled estimate of RR for these studies is 1.02 (95\% CI: $0.64,1.62)$ using the random effect model with high observed heterogeneity $\left(\mathrm{I}^{2}=80 \%, \mathrm{P}\right.$ $<0.0001$ ) (Figure 3).

\section{Effect of Vitamin D serum concentration on ICU admission}

Only three studies reported ICU admission. There were $67 / 332(20 \%)$ and $114 / 457(25 \%)$ patients admitted to the ICU in the low serum concentration 
group and normal serum concentration group respectively. The pooled estimated RR was 0.87 $(95 \%$ CI: $0.67,1.14)$ with low heterogeneity $\left(\mathrm{I}^{2}=\right.$ $0 \%, \mathrm{p}=0.49)$ Figure 4.

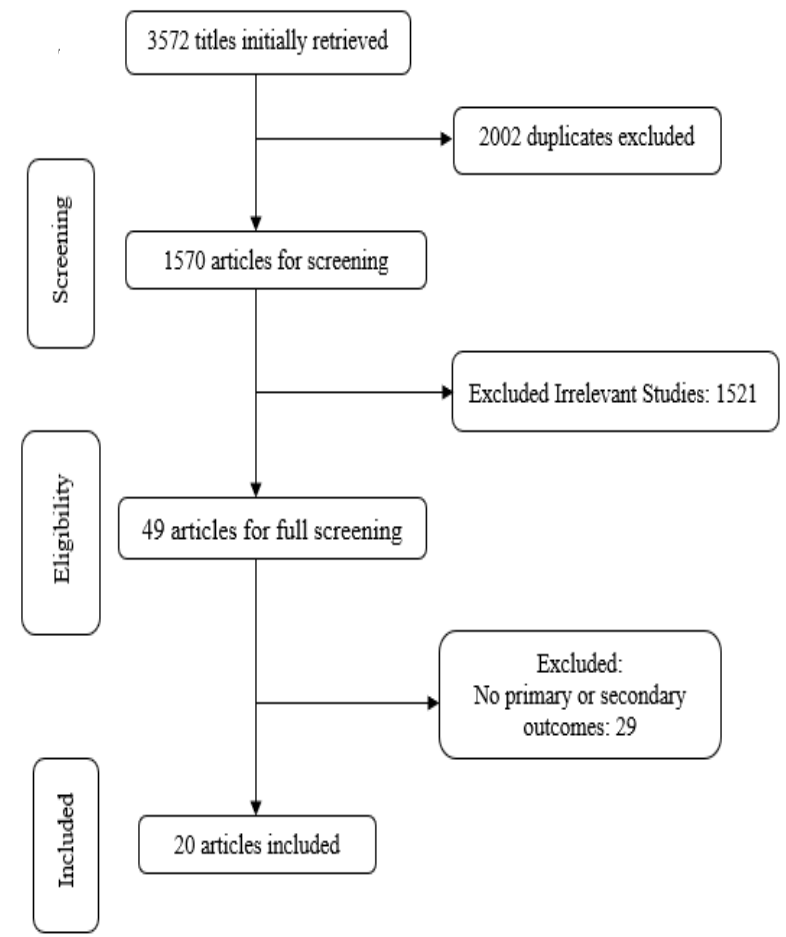

Figure 1. Search Strategy. The characteristics of the studies are summarized in Table 1. A total of 12,806 patients aged between 42 to 81 years old were analyzed. The studies were conducted in United Kingdom (3), Italy (3), United States (2), Iran (2), Germany (2), India (2), Pakistan (1), Thailand (1), Spain (1), Turkey (1), China (1), and Greece (1). The pre-defined Vitamin D serum concentrations varied significantly in the studies. Because the studies are observational studies, the quality of the studies were not assessed as they all have high risk of bias.

\section{The effect of Vitamin D serum concentration on ventilator support requirement.}

The reported number of patients requiring ventilator support for the low serum concentration and normal concentration were 267/708 (38\%) and 233/920 (25\%) respectively. The pooled estimate RR was 1.29 (95\% CI: $0.79,1.84)$ with high heterogeneity observed between studies $\left(\mathrm{I}^{2}=86 \%, \mathrm{P}<0.00001\right)$ (Figure 5). The study from Radujkovic was removed from the analysis and the results showed no difference.

\section{Length of hospital stay}

A total of six studies reported the length of hospital stay. The pooled estimate mean difference was 0.84
(95\% CI $-0.45,2.13)$ with low heterogenicity observed between studies $\left(\mathrm{I}^{2}=0 \%, \mathrm{P}=0.90\right)$ (Figure 6).

\section{DISCUSSION}

In this meta-analysis, the results show that Vitamin D serum concentration was not statistically associated with mortality and ICU admission, ventilator support requirement, and length of hospital stay. The studies included in the meta-analysis had various pre-define concentration as low. We conducted a subgroup analysis of the studies with a defined low concentration as $<20 \mathrm{ng} / \mathrm{mL}$ since the normal Vitamin D serum concentration is $>20$ $\mathrm{ng} / \mathrm{mL}$ (33). The results did not show a difference. In addition, removing the studies with wide CI did not make a difference.

Vitamin D is a hormone that regulates both innate and adaptive immune responses. Some observational studies showed that patients with respiratory diseases who have higher 25hydroxyvitamin D levels have better clinical outcomes (34). Vitamin D regulates the inflammatory and oxidative pathways which are triggered in COVID-19 patients (35). In addition, Vitamin D maintains cellular homeostasis (34) by modulating the renin-angiotensin-aldosterone system (RAAS) pathways (36). The RAAS regulates body electrolytes and hemodynamics. It has been observed that serum angiotensin II levels are significantly elevated in COVID-19 infection which is correlated with COVID-19 viral load and lung damage (37). The COVID-19 virus binds to angiotensin-converting enzyme 2 (ACE2) receptors to attack human lung epithelial cells and trigger an infection (38-40). The binding of the ACE2 receptors results in ACE2 inhibiting inflammatory, oxidant, fibrotic, and hyperplasia effects. Moreover, with COVID-19 blocking the ACE2 receptors, the angiotensin II will metabolize ACE2. This results in an accumulation of toxicity, which causes acute respiratory syndrome in patients with COVID-19 (41-43). Vitamin D is a potent suppressor in producing renin (44). When Vitamin D is low, the renin level is high which will put the RAAS in overdrive and resulting in an overproduction of angiotensin II $(34,45)$. It is shown that Vitamin D deficiency can cause an over production of the angiotensin converting enzymes (ACE and ACE2) (46). The active form of Vitamin D $(1,25-$ dihydroxyvitamin D) is also called calcitriol which 
inhibits the production and secretion of many cytokines from the smooth bronchial smooth muscle

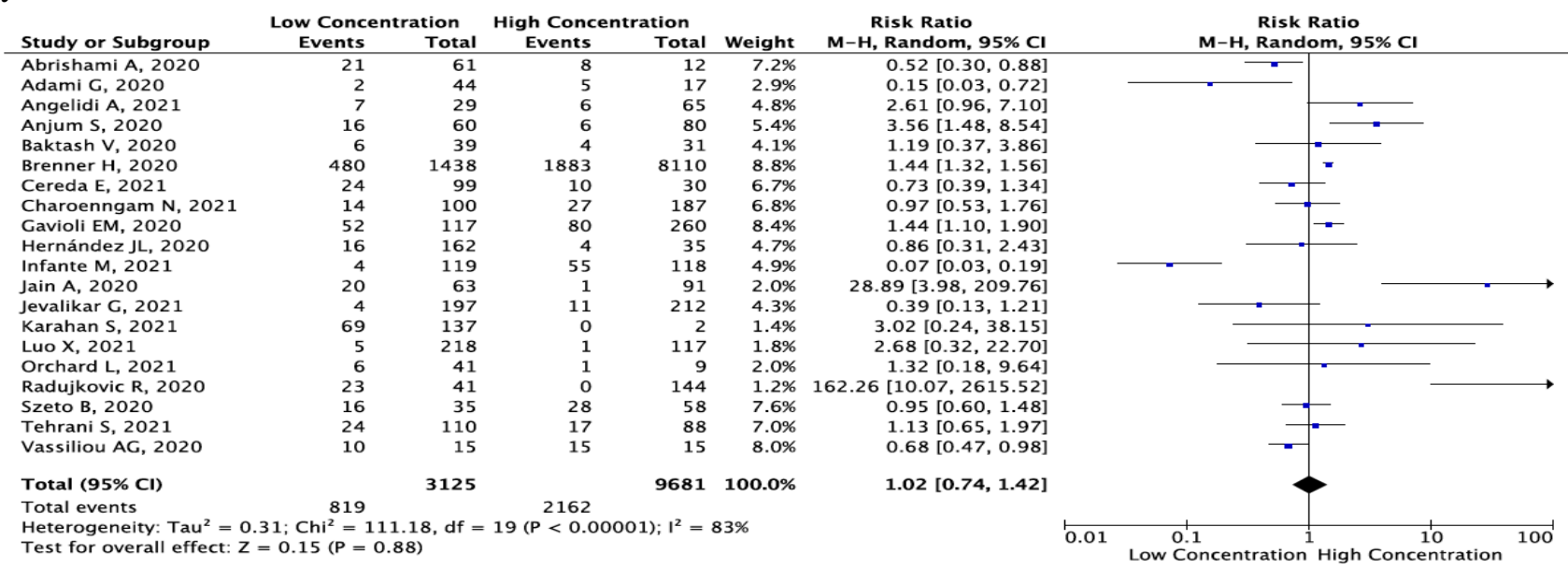

Figure 2. Vitamin D serum concentration and mortality.

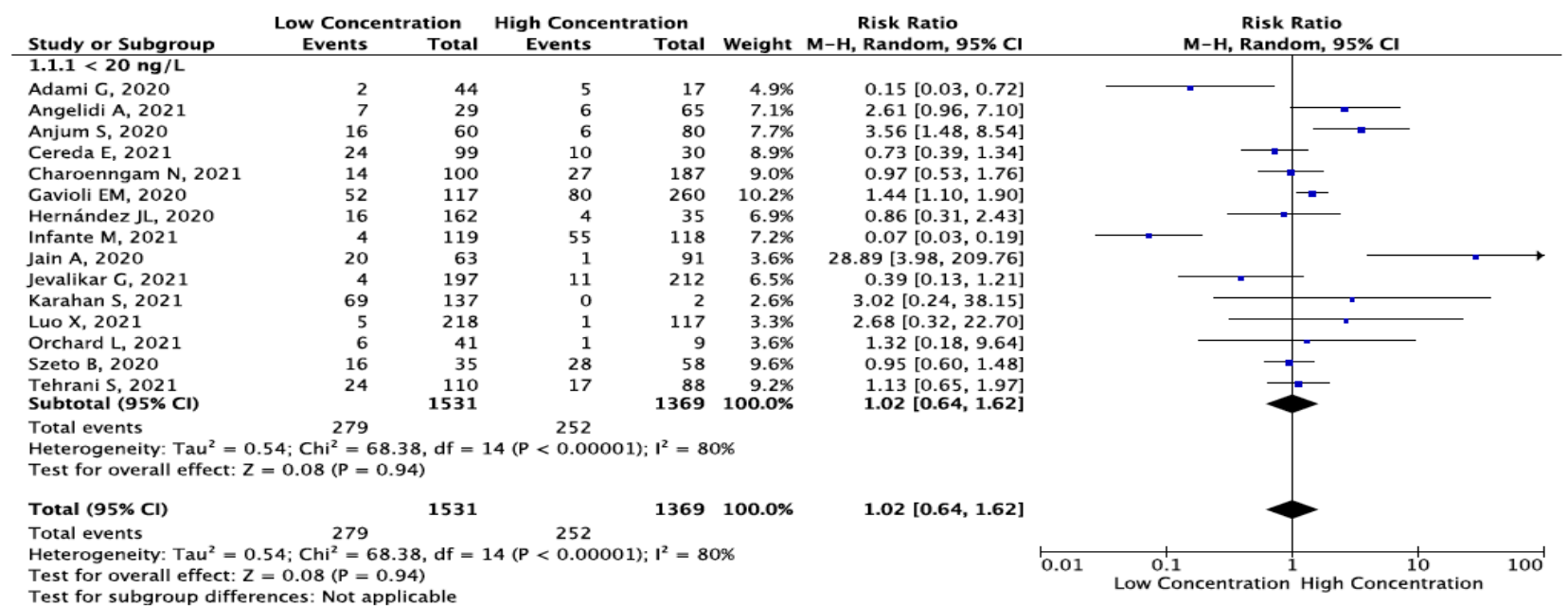

Figure 3. Vitamin D serum concentration of $<20 \mathrm{ng} / \mathrm{mL}$ and mortality.

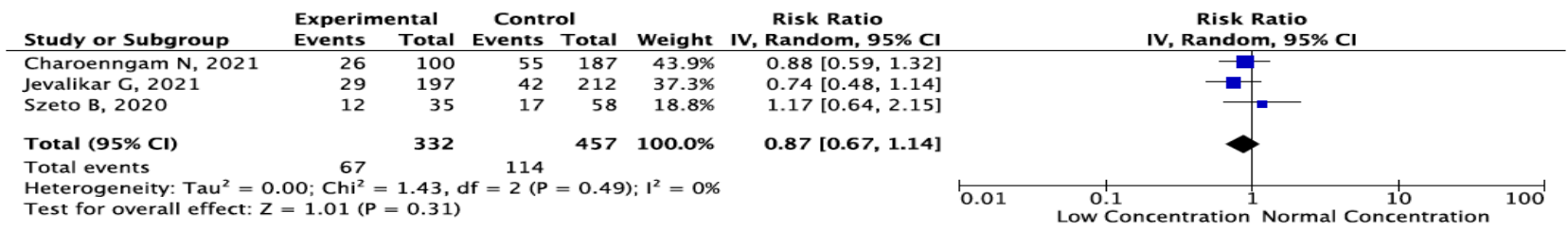

Figure 4. ICU admission between low Vitamin D concentration and normal Vitamin D concentration.

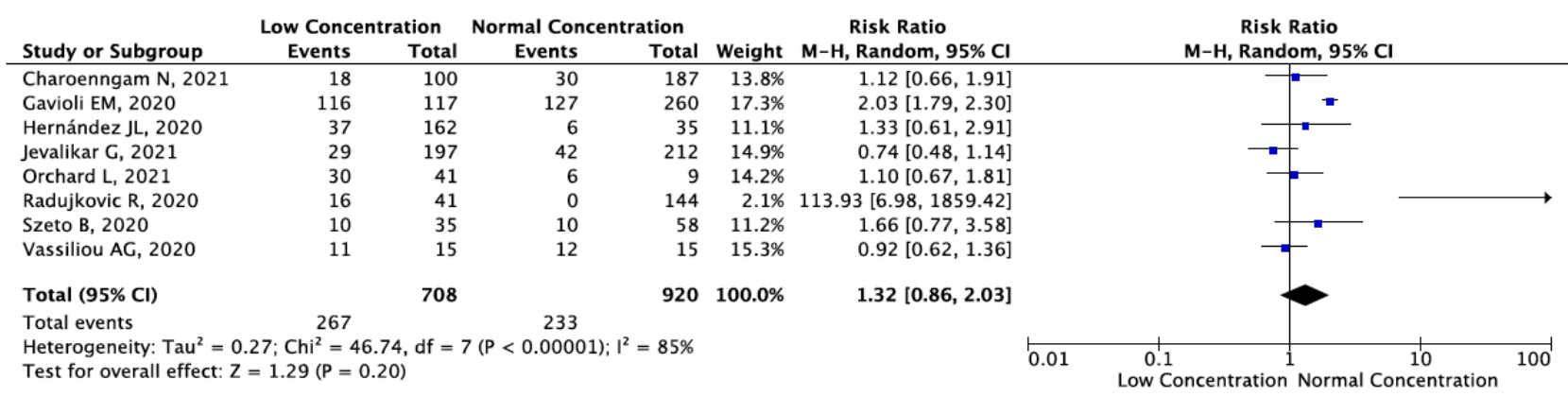


Figure 5. Ventilator support requirement.

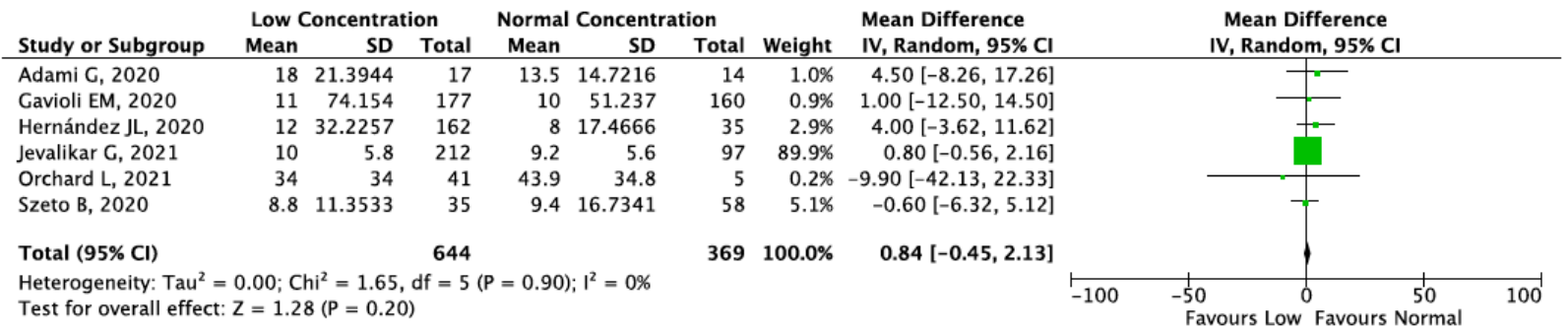

Figure 6. Length of hospital stay.

Table 1. Basic characteristics of studies

\begin{tabular}{|c|c|c|c|c|c|}
\hline Author, year & Design/Country & $\begin{array}{l}\text { Patients } \\
\text { characteristics, } \\
\text { sample size }\end{array}$ & Outcomes & $\begin{array}{l}\text { Low Concentration } \\
\text { (G1) }\end{array}$ & $\begin{array}{l}\text { Normal } \\
\text { Concentration (G2) }\end{array}$ \\
\hline Abrishami A, 2020 & $\begin{array}{l}\text { Retrospective } \\
\text { Iran }\end{array}$ & $\begin{array}{l}\text { Patients: } 73 \text { (G1=61, } \\
\text { G2=12) }\end{array}$ & Mortality & $38.41 \pm 18.51(21)$ & $13.83 \pm 12.53(8)$ \\
\hline Adami G, 2021 & $\begin{array}{l}\text { Retrospective } \\
\text { Italy }\end{array}$ & $\begin{array}{l}\text { Patients: } 61 \text { (G1=44, } \\
\text { G2=17) }\end{array}$ & Mortality & $<20 \mathrm{ng} / \mathrm{mL}$ & $\geq 20 \mathrm{ng} / \mathrm{mL}$ \\
\hline Angelidi A, 2021 & $\begin{array}{l}\text { Retrospective, } \\
\text { Observational } \\
\text { United States }\end{array}$ & $\begin{array}{l}\text { Patients: } 144(\mathrm{G} 1=29, \\
\mathrm{G} 2=65)\end{array}$ & Mortality & $<30 \mathrm{ng} / \mathrm{mL}$ & $\geq 30 \mathrm{ng} / \mathrm{mL}$ \\
\hline Anjum S, 2020 & $\begin{array}{l}\text { Prospective, } \\
\text { Observational } \\
\text { Pakistan }\end{array}$ & $\begin{array}{l}\text { Patients: } 140(\mathrm{G} 1=60 \text {, } \\
\mathrm{G} 2=80)\end{array}$ & Mortality & $<25 \mathrm{nmol} / \mathrm{L}$ & $\geq 25 \mathrm{nmol} / \mathrm{L}$ \\
\hline Baktash V, 2020 & $\begin{array}{l}\text { Prospective, Cohort } \\
\text { United Kingdom }\end{array}$ & $\begin{array}{l}\text { Patients: } 70(\mathrm{G} 1=39, \\
\mathrm{G} 2=31)\end{array}$ & Mortality & $\leq 30 \mathrm{nmol} / \mathrm{L}$ & $>30 \mathrm{nmol} / \mathrm{L}$ \\
\hline Brenner H, 2020 & $\begin{array}{l}\text { Retrospective } \\
\text { Germany }\end{array}$ & $\begin{array}{l}\text { Patients: } 9548(\mathrm{G} 1= \\
\text { 1438, G2=8110) }\end{array}$ & Mortality & $<30 \mathrm{nmol} / \mathrm{L}$ & $\geq 30 \mathrm{nmol} / \mathrm{L}$ \\
\hline Cereda E, 2021 & $\begin{array}{l}\text { Prospective } \\
\text { Italy }\end{array}$ & $\begin{array}{l}\text { Patients: } 129(\mathrm{G} 1=99, \\
\mathrm{G} 2=30)\end{array}$ & Mortality & $<30 \mathrm{ng} / \mathrm{mL}$ & $\geq 30 \mathrm{ng} / \mathrm{mL}$ \\
\hline $\begin{array}{l}\text { Charoenngam N, } \\
2021\end{array}$ & $\begin{array}{l}\text { Retrospective } \\
\text { Thailand }\end{array}$ & $\begin{array}{l}\text { Patients: } 287(\mathrm{G} 1= \\
100, \mathrm{G} 2=187)\end{array}$ & $\begin{array}{l}\text { Mortality } \\
\text { Intubation }\end{array}$ & $<30 \mathrm{ng} / \mathrm{mL}$ & $\geq 30 \mathrm{ng} / \mathrm{mL}$ \\
\hline Gavioli EM, 2020 & $\begin{array}{l}\text { Retrospective, } \\
\text { Observational } \\
\text { United Kingdom }\end{array}$ & $\begin{array}{l}\text { Patients: } 437(\mathrm{G} 1= \\
117, \mathrm{G} 2=260)\end{array}$ & $\begin{array}{l}\text { Mortality } \\
\text { Intubation }\end{array}$ & $<20 \mathrm{ng} / \mathrm{mL}$ & $\geq 20 \mathrm{ng} / \mathrm{mL}$ \\
\hline Hernández JL, 2020 & $\begin{array}{l}\text { Retrospective, } \\
\text { Observational } \\
\text { Spain }\end{array}$ & $\begin{array}{l}\text { Patients: } 216(\mathrm{G} 1= \\
162, \mathrm{G} 2=35)\end{array}$ & $\begin{array}{l}\text { Mortality } \\
\text { Intubation }\end{array}$ & $<20 \mathrm{ng} / \mathrm{mL}$ & $\geq 20 \mathrm{ng} / \mathrm{mL}$ \\
\hline Infante M, 2021 & $\begin{array}{l}\text { Retrospective } \\
\text { Italy }\end{array}$ & $\begin{array}{l}\text { Patients: }(\mathrm{G} 1=19, \mathrm{G} 2= \\
118)\end{array}$ & Mortality & $<20 \mathrm{ng} / \mathrm{mL}$ & $\geq 20 \mathrm{ng} / \mathrm{mL}$ \\
\hline Jain A, 2020 & $\begin{array}{l}\text { Prospective, } \\
\text { Observational } \\
\text { India }\end{array}$ & $\begin{array}{l}\text { Patients: } 154(\mathrm{G} 1=63 \text {, } \\
\mathrm{G} 2=91)\end{array}$ & Mortality & $14.35 \pm 5.79 \mathrm{ng} / \mathrm{mL}$ & $27.89 \pm 6.21 \mathrm{ng} / \mathrm{mL}$ \\
\hline Jevalikar G, 2021 & $\begin{array}{l}\text { Prospective, Cross } \\
\text { sectional } \\
\text { India }\end{array}$ & $\begin{array}{l}\text { Patients: } 410(\mathrm{G} 1= \\
197, \mathrm{G} 2=212)\end{array}$ & $\begin{array}{l}\text { Mortality } \\
\text { ICU Intubation }\end{array}$ & $<20 \mathrm{ng} / \mathrm{mL}$ & $\geq 20 \mathrm{ng} / \mathrm{mL}$ \\
\hline Karahan S, 2021 & $\begin{array}{l}\text { Retrospective, } \\
\text { Observational } \\
\text { Turkey }\end{array}$ & $\begin{array}{l}\text { Patients: } 149(\mathrm{G} 1= \\
137, \mathrm{G} 2=2)\end{array}$ & Mortality & $\leq 30 \mathrm{ng} / \mathrm{mL}$ & $>30 \mathrm{ng} / \mathrm{mL}$ \\
\hline Luo X, 2021 & $\begin{array}{l}\text { Retrospective, Cross } \\
\text { sectional } \\
\text { China }\end{array}$ & $\begin{array}{l}\text { Patients: } 335(\mathrm{G} 1= \\
218, \mathrm{G} 2=117)\end{array}$ & Mortality & $<30 \mathrm{nmol} / \mathrm{L}$ & $\geq 30 \mathrm{nmol} / \mathrm{L}$ \\
\hline Orchard L, 2021 & $\begin{array}{l}\text { Retrospective Cohort } \\
\text { study } \\
\text { United Kingdom }\end{array}$ & $\begin{array}{l}\text { Patients: } 50(\mathrm{G} 1=41, \\
\mathrm{G} 2=9)\end{array}$ & $\begin{array}{l}\text { Mortality } \\
\text { Intubation }\end{array}$ & $50 \mathrm{nmol} / \mathrm{L}$ & $>50 \mathrm{nmol} / \mathrm{L}$ \\
\hline Radujkovic R, 2020 & $\begin{array}{l}\text { Prospective, } \\
\text { Observational } \\
\text { Germany }\end{array}$ & $\begin{array}{l}\text { Patients: } 185(\mathrm{G} 1=41, \\
\mathrm{G} 2=144)\end{array}$ & $\begin{array}{l}\text { Mortality } \\
\text { Intubation }\end{array}$ & $<12 \mathrm{ng} / \mathrm{mL}$ & $\geq 12 \mathrm{ng} / \mathrm{mL}$ \\
\hline Szeto B, 2020 & $\begin{array}{l}\text { Retrospective, Cohort } \\
\text { United States }\end{array}$ & $\begin{array}{l}\text { Patients: } 93(\mathrm{G} 1=35, \\
\mathrm{G} 2=58)\end{array}$ & $\begin{array}{l}\text { Mortality } \\
\text { ICU Intubation }\end{array}$ & $<20 \mathrm{ng} / \mathrm{mL}$ & $\geq 20 \mathrm{ng} / \mathrm{mL}$ \\
\hline Tehrani S, 2021 & $\begin{array}{l}\text { Retrospective } \\
\text { Iran }\end{array}$ & $\begin{array}{l}\text { Patients: } 205(\mathrm{G} 1=110 \text {, } \\
\mathrm{G} 2=88, \mathrm{G} 3=7)\end{array}$ & Mortality & $<30 \mathrm{ng} / \mathrm{ml}$ & $\begin{array}{l}\geq 30 \mathrm{ng} / \mathrm{ml} \\
>100 \mathrm{ng} / \mathrm{ml}\end{array}$ \\
\hline Vassiliou AG, 2020 & $\begin{array}{l}\text { Prospective, } \\
\text { Observational } \\
\text { Greece }\end{array}$ & $\begin{array}{l}\text { Patients: } 30(\mathrm{G} 1=15, \\
\mathrm{G} 2=15)\end{array}$ & $\begin{array}{l}\text { Mortality } \\
\text { Intubation }\end{array}$ & $<15.2 \mathrm{ng} / \mathrm{mL}$ & $\geq 15.2 \mathrm{ng} / \mathrm{mL}$ \\
\hline
\end{tabular}


*One $\mathrm{nmol} / \mathrm{L}$ is equal to $0.4 \mathrm{ng} / \mathrm{mL}$, and $1 \mathrm{ng} / \mathrm{mL}$ is equal to $2.5 \mathrm{nmol} / \mathrm{L}$. cells (47-48). It has been proposed that Vitamin D provides a natural anti-inflammatory and antioxidant effect resulting in improved clinical outcomes in patients with COPD (chronic obstructive pulmonary disease) (49). A possible focus in the management of COVID-19 is supplementing Vitamin D in order to prevent or reverse the inflammatory process from the RAAS (50).

Several recent studies suggest patients receiving Vitamin D supplements targeting a serum concentration could reduce the risk of influenza and COVID-19 infections (51-53). This meta-analysis suggests no statistical difference in mortality, ICU admission, and ventilator support requirement between low and normal serum concentration of vitamin D in patients with COVID-19. This renders the determination of the optimal 25dihydroxyvitamin $\mathrm{D}$ serum concentration required for COVID-19 infection challenge.

The most effective and safe dose to administer to achieve a targeted Vitamin D serum concentration is also unknown. A proposed dosing for patients with COVID-19 is between 5,000 IU or 10,000 IU daily, or 50,000 IU to 100,000 IU weekly (52). Additional randomized controlled trials are needed to determine the ideal dose and Vitamin D serum concentration required for attenuation of COVID-19 infection.

Vitamin D has proven to play an important role in calcium absorption and prevention of osteoporosis (54). In addition, observational studies showed a strong correlation between Vitamin D and cancer, type 1 diabetes, and heart diseases (55). It is essential that adequate Vitamin D supplement is consumed to maintain healthy bone and normal calcium metabolism in healthy individuals. Currently, Health Canada recommends daily intake of Vitamin D between $400 \mathrm{IU}$ and $800 \mathrm{IU}$ (56).

\section{Limitations}

The meta-analysis consists of 20 observational studies, and they all have high risk of publication bias. Most of the studies are retrospective studies which present a potential risk of bias. The sample size is very small in all but one study (Brenner) which leads to inadequate statistical power. The defined low concentration varied significantly among the pooled analysis. Most of these studies did not disclose if the patients were receiving supplemental Vitamin D and Vitamin D serum concentrations used in the studies are not consistent. In addition, not all of the studies reported the co-morbidities existing in the patients with COVID-19 infection. Lastly, potential confounders such as administration of antiretroviral medications, convalescent plasma or SARS-CoV-2 antibody-based intravenous immunoglobulin therapy which could affect clinical outcomes were given to patients in many of the studies and may cause bias.

\section{CONCLUSION}

There is no statistical difference in mortality, $\{R R$ 1.02 (95\% CI: $0.74,1.42)\}$, ICU admission rate, $\{$ RR $0.87(95 \%$ CI: $0.67,1.14)\}$ and ventilator support requirement, $\{\mathrm{RR}$ was 1.29 (95\% CI: $0.79,1.84)\}$, and length of hospital stay $\{0.84$ (95\% CI -0.45 , 2.13)\} in COVID-19 patients with low and high Vitamin D serum concentration. Additional randomized controlled trials are needed to provide a specific supplemental vitamin dose and Vitamin D serum concentration to target.

\section{CONFLICT OF INTEREST. None.}

\section{REFERENCES}

1. WHO. WHO Director-General's Opening Remarks at the Media Briefing on COVID19-11 March 2020. Available online:https://www.who.int/directorgeneral/speeches/detail/who-director-generals-opening-remarks-at-the-media-briefingoncovid-19---11-march-2020 (accessed on March 23, 2021).

2. Giannis D, Ziogas IA, Gianni P. Coagulation disorders in coronavirus infected patients: COVID-19, SARS-CoV-1, MERS-CoV and lessons from the past. J Clin Virol 2020;127:104362.

3. Lu D, Zhang J, Ma C et al. Link between community-acquired pneumonia and vitamin D levels in older patients. Z Gerontol Geriatr 2018;51:435-9.

4. Science M, Maguire JL, Russell ML et al. Low serum 25-hydroxyvitamin D level and risk of upper respiratory tract infection in children and adolescents. Clin Infect Dis 2013;57:3927.

5. Grant WB, Giovannucci E. The possible roles of solar ultraviolet-B radiation and vitamin D in reducing case-fatality rates from the 19181919 infuenza pandemic in the United States. Dermatoendocrinol. 2009;1:215-219. 
6. Margetic, S. Inflammation and haemostasis. Biochem. Med. (Zagreb) 2012, 22, 49-62.

7. Peterson CA, Heffernan ME. Serum tumor necrosis factor-alpha concentrations are negatively correlated with serum $25(\mathrm{OH}) \mathrm{D}$ concentrations in healthy women. J Inflamm (London) 2008;5:10.

8. Liberati A, Altman DG, Tetzlaff J, et al. The PRISMA Statement for Reporting Systematic Reviews and Meta-Analyses of Studies That Evaluate Health Care Interventions: Explanation and Elaboration. Vol 62.; 2009. doi:10.1016/j. jclinepi.2009.06.006. doi: 10.1186/s13643-017-0663-8

9. Jagannath VA, Filippini G, Di Pietrantonj C, Asokan GV, Robak EW, Whamond L, Robinson SA. Vitamin D for the management of multiple sclerosis. Cochrane Database of Systematic Reviews 2018, Issue 9. Art. No.: CD008422.

DOI:

10.1002/14651858.CD008422.pub3.

Accessed 11 March 2021.

10. Ma J (13 March 2020). "Coronavirus: China's first confirmed Covid-19 case traced back to November 17". South China Morning Post. https://www.scmp.com/news/china/society/ar ticle/3074991/coronavirus-chinas-firstconfirmed-covid-19-case-traced-back Accessed 11 March 2021.

11. Covidence systematic review software, Veritas Health Innovation, Melbourne, Australia. Available at www.covidence.org

12. Haddaway NR, Collins AM, Coughlin D, Kirk S. The Role of Google Scholar in Evidence Reviews and Its Applicability to Grey Literature Searching. PLoS ONE. 2015;10(9):1-17.

doi:10.1371/journal.pone.0138237.

13. Abrishami A, Dalili N, Torbati PM, Asgari R, Arab-Ahmadi M, Behnam BM, et al. Possible association of vitamin D status with lung involvement and outcome in patients with COVID-19: a retrospective study. Eur J Nutr. 2021;60:2249-57.

14. Adami G, Giollo A, Fassio A, Benini C, Bertoldo E, Bertoldo F, et al. Vitamin D and disease severity in coronavirus disease 19 (COVID-19) Reumatismo. 2021;72:189-96.

15. Angelidi AM, Belanger MJ, Lorinsky MK, Karamanis D, Chamorro-Pareja N, Ognibene $\mathrm{J}$, Palaiodimos, et al. Vitamin D status is associated with in-hospital morality and mechanical ventilation: a cohort of COVID-19 hospitalized patients. Mayo Clin Proc. 2021;96:875-86.

16. Anjum S, Suleman S, Afridi S, Yasmeen G, Shah MI. Examine the association between severe vitamin D deficiency and mortality in patients with Covid-19. Pakistan J Medical Health Sci. 2020;14:1184-6.

17. Baktash V, Hosack T, Patel N, Shah S, Kandiah P, Van den Abbeele K, Missouri CG. Vitamin D status and outcomes for hospitalised older patients with COVID-19. Postgrad Med J. 2021;97:442-7.

18. Brenner H, Holleczek B, Schottker B. Vitamin $\mathrm{D}$ insufficiency and deficiency and mortality from respiratory diseases in a cohort of older adults: potential for limiting the death toll during and beyond the COVID-19 pandemic? Nutrients. 2020;12:2488. doi: 10.3390/nu12082488.

19. Cereda E, Bogliolo L, Klersy C, Lobascio F, Masi S, Crotti S, et al. Vitamin D $25 \mathrm{OH}$ deficiency in COVID-19 patients admitted to a tertiary referral hospital. Clin Nutr. 2021;40:2469-72.

20. Charoenngam N, Shirvani A, Reddy N, Vodopivec DM, Apovian CM, Hollick MF. Association of vitamin D status with hospital morbidity and mortality in adult hospitalized patients with COVID-19. Endocr Pract. 2021;27:271-8.

21. Gavioli EM, Misyashita H, Hassaneen O, Siau E. An evaluation of serum 25-hydroxy vitamin D levels in patients with COVID-19 in New York City. J Am Coll Nutr. 2021;19-1-6. doi: 10.1080/07315724.2020.1869626

22. Hernandez JL, Nan D, Fernandez-Ayala M, Gercia-Unzueta M, Hernandez-Hernandez MA, Lopez-Hoyos M. Vitamin D status in hospitalized patients with SARS-CoV-2 infection. $\mathrm{J}$ Clin Endocrinol Metab. 2021;106:e1343-53.

23. Infante $\mathbf{M}$, Buoso $\mathrm{A}$, Pieri $\mathrm{M}$, Lupisella $\mathrm{S}$, Nuccetelli M, Bernardi S, et al. Low vitamin $\mathrm{D}$ status at admission as a risk factor for poor survival in hospitalized patients with COVID19: an Italian retrospective study. J Am Coll Nutr. 2021;18:1-16.

24. Jian A, Chaurasia R, Sengar NS, Singh M, Mahor S, Narain S. Analysis of vitamin D level among asymptomatic and critically ill COVID-19 patients and its correlation with inflammatory markers. Sci Rep. 
2020;19:20191. doi: 10.1038/s41598-02077093-z.

25. Jevalikar G, Mithal A, Singh A, Sharma R, Farooqui KJ, Mahendru S, et al. Lack of association of baseline 25-hydroxyvitamin D levels with disease severity and mortality in Indian patients hospitalized for COVID-19. Sci Rep. 2021;11:6258. doi: 10.1038/s41598021-85809-y.

26. Karahan S, Katkat F. Impact of serum $25(\mathrm{OH})$ vitamin $\mathrm{D}$ level on mortality in patients with COVID-19 in Turkey. J Nutr Health Aging. 2021;25:189-96.

27. Luo X, Liao Q, Shen Y, Li H, Cheng L. Vitamin D deficiency is associated with COVID-19 incidence and disease severity in Chinese people. Nutr. 2021;15:98-103.

28. Orchard L, Baldry M, Nasim-Mohi M, Monck C, Saeed K, Grocott MP, et al. Vitamin-D levels and intensive care unit outcomes of a cohort of critically ill COVID-19 patients. Clin Chem Lab Med. 2021;59:1155-63.

29. Radujkovic A, Hippchen T, Tiwar-Heckler S, Dreher S, Boxberger M, Merle U. Vitamin D deficiency and outcome of COVID-19 patients. Nutr. 2020;12:2757. doi: 10.3390/nu12092757.

30. Szeto B, Zucker JE, LaSota ED, Rubin MR, Walker MD, Yin MT, et al. Vitamin D status and COVID-19 clinical outcomes in hospitalized patients. Endocr Res. 2021;46:6673.

31. Tehrani S, Khabiri N, Moradi H, Mosavat MS, Khabiri S. Evaluation of vitamin D levels in COVID-19 patients referred to Labafinejad hospital in Tehran and its relationship with disease severity and morality. Clin Nutr ESPEN. 2021;42:313.

32. Vassiliou A, Jahai E, Pratikaki M, Orfanos SE, Dimopoulou I, Kotanidou A. Low 25hydroxyvitamin D levels on admission to the intensive care unit may predispose COVID-19 pneumonia patients to a higher 28-day mortality risk: a pilot study on a Greek ICU cohort. Nutrients. 2020;12:3773. doi: 10.3390/nu12123773.

33. Institute of Medicine (2011) Dietary Reference Intakes for Calcium and Vitamin D. Washington, DC: National Academies Press.

34. Cannell JJ, Vieth R, Umhau JC, et al. Epidemic influenza and vitamin D. Epidemiol
Infect. 2006;134:1129-1140. doi:10.1017/S0950268806007175

35. Christakos S, Raval-Pandya M, Wernyj RP, Yang W. Genomic mechanisms involved in the pleiotropic actions of 1,25dihydroxyvitamin D3. Biochem J. 1996;316: 361-71. doi:10.1042/bj3160361.

36. Hossein-nezhad A, Spira A, Holick MF. Influence of vitamin D status and vitamin D3 supplementation on genome wide expression of white blood cells: a randomized doubleblind clinical trial. PLoS One 8: e58725, 2013. doi:10.1371/journal.pone.0058725.

37. Liu Y, Yang Y, Zhang C, Huang F, Wang F, Yuan J, et al. Clinical and biochemical indexes from 2019-nCoV infected patients linked to viral loads and lung injury. SciChina Life Sci. 2020;63: 364-74. doi:10.1007/s11427-0201643-8.

38. Cheng H, Wang Y,Wang GQ. Organprotective effect of angiotensin-converting enzyme 2 and its effect on the prognosis of COVID-19. J Med Virol. 2020;92: 726-30. doi:10.1002/jmv.25785.

39. Danser AHJ, Epstein M, Batlle D. Reninangiotensin system blockers and the COVID19 pandemic: at present there is no evidence to abandon renin-angiotensin system blockers. Hypertension. 2020;75:1382-85. doi:10.1161/HYPERTENSIONAHA.120.150 82.

40. Sun ML, Yang JM, Sun YP, Su GH. Inhibitors of RAS might be a good choice for the therapy of COVID-19 pneumonia. Zhonghua Jie He $\mathrm{He} \quad \mathrm{Hu} \quad \mathrm{Xi} \mathrm{Za}$ Zhi.2020;43: E014. doi:10.3760/cma.j.issn.1001-0939.2020.0014.

41. Vaduganathan M, Vardeny $\mathrm{O}$, Michel T, McMurray JJV, Pfeffer MA, Solomon SD. Renin-angiotensin-aldosterone system inhibitors in patients with Covid-19. N Engl J Med. 2020;382: 1653-9. doi:10.1056/NEJMsr2005760

42. Cheng H, Wang Y,Wang GQ. Organprotective effect of angiotensin-converting enzyme 2 and its effect on the prognosis of COVID-19. J Med Virol. 2020;92: 726-30. doi:10.1002/jmv.25785.

43. Danser AHJ, Epstein M, Batlle D. Reninangiotensin system blockers and the COVID19 pandemic: at present there is no evidence to abandon renin-angiotensin system blockers. Hypertension. 
doi:10.1161/HYPERTENSIONAHA.120.150 82.

44. Ferder M, Inserra F, Manucha W, Ferder L. The world pandemic of vitamin D deficiency could possibly be explained by cellular inflammatory response activity induced by the renin-angiotensin system. Am J Physiol Cell Physiol. 2013;304: C1027-C1039. doi:10.1152/ajpcell.00403.2011.

45. Li YC, Qiao G, UskokovicM, XiangW, ZhengW, Kong J. Vitamin D: a negative endocrine regulator of the renin-angiotensin system and blood pressure. J Steroid Biochem Mol Biol 89-90: 387-392, 2004. doi:10.1016/j.jsbmb.2004.03.004.

46. $\quad \mathrm{Xu} \mathrm{J}$, Yang J, Chen J, Luo Q, Zhang Q, Zhang $\mathrm{H}$. Vitamin D alleviates lipopolysaccharideinduced acute lung injury via regulation of the renin-angiotensin system. Mol Med Rep 16: 7432-7438, 2017. doi:10.3892/mmr.2017.7546.

47. ChenWW, Cai XX, TianWM, Shang YX. Expression of RANTES in the lung tissue of asthmatic rats, and the intervention effect of vitamin D on RANTES expression. Zhongguo Dang Dai Er Ke Za Zhi. 2012;14: 863-8.

48. Chung C, Silwal P, Kim I, Modlin RL, Jo EK. Vitamin D-cathelicidin axis: at the crossroads between protective immunity and pathological inflammation during infection. Immune Netw. 20:e12, 2020. doi:10.4110/in.2020.20.e12.

49. Sandhu MS, Casale TB. The role of vitamin D in asthma. Ann Allergy Asthma Immunol 105: 191-199, 2010. doi:10.1016/j.anai.2010.01.013.

50. Biswas S, Hwang JW, Kirkham PA, Rahman I. Pharmacological and dietary antioxidant therapies for chronic obstructive pulmonary disease. Curr Med Chem. 2013;20: 14961530. doi:10.2174/0929867311320120004.

51. Laird E, Kenny RA. Vitamin D Deficiency in Ireland - Implications for COVID-19. Results from the Irish Longitudinal Study on Ageing. Dublin: The Irish Longitudinal Study on Ageing (TILDA), 2020, doi:10.38018/TildaRe.2020-05.

52. Grant WB, Lahore $\mathrm{H}$, McDonnell SL, Baggerly CA, French CB, Aliano JL, Bhattoa HP. Evidence that vitamin D supplementation could reduce risk of influenza and COVID-19 infections and deaths. Nutrients. 2020;12: E988. doi:10.3390/nu12040988.

53. Ekwaru JP, Zwicker JD, HolickMF, Giovannucci E, Veugelers PJ. The importance of body weight for the dose response relationship of oral vitamin $\mathrm{D}$ supplementation and serum 25-hydroxyvitamin D in healthy volunteers. PLoS One 9: e111265, 2014. doi:10.1371/journal.pone.0111265.

54. Holick MF. Vitamin D: importance in the prevention of cancers, type 1 diabetes, heart disease and osteoporosis. Am J Clin Nutr. 2004;79:362-71.

55. Wang H, Chen W, Li D, Yin X, Zhang X, Olsen N, et al. Vitamin D and chronic diseases. Agng Dis. 2017;8:346-53.

56. Vitamin D and calcium: updated dietary reference intakes.

https://www.canada.ca/en/healthcanada/services/food-nutrition/healthyeating/vitamins-minerals/vitamin-calciumupdated-dietary-reference-intakesnutrition.html. Accessed on January 21, 2022. 